\title{
Introduction. From Diaspora Politics to Host- society Politics: Strategies of Political Mobilization and Integration of South Asian Migrants
}

Anne-Sophie Bentz and Lola Guyot

\section{OpenEdition}

\section{Journals}

Electronic version

URL: https://journals.openedition.org/samaj/7728

DOI: $10.4000 /$ samaj. 7728

ISSN: $1960-6060$

Publisher

Association pour la recherche sur l'Asie du Sud (ARAS)

Electronic reference

Anne-Sophie Bentz and Lola Guyot, "Introduction. From Diaspora Politics to Host-society Politics:

Strategies of Political Mobilization and Integration of South Asian Migrants", South Asia

Multidisciplinary Academic Journal [Online], 27 | 2021, Online since 02 February 2022, connection on 15

March 2022. URL: http://journals.openedition.org/samaj/7728 ; DOI: https://doi.org/10.4000/samaj. 7728

This text was automatically generated on 15 March 2022.

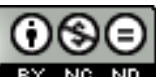

This work is licensed under a Creative Commons Attribution-NonCommercial-NoDerivatives 4.0 International License. 


\title{
Introduction. From Diaspora Politics to Host-society Politics: Strategies of Political Mobilization and Integration of South Asian Migrants
}

\author{
Anne-Sophie Bentz and Lola Guyot
}

1 This Special Issue on the political mobilization of South Asian migrants is the outcome of a series of collaborative projects which started in 2019: a panel convened at the annual convention of the Association for the Study of Nationalities (ASN) at Columbia University (New York); a conference cycle organized at Université de Paris (CESSMA); and a panel proposed for the annual conference of the British

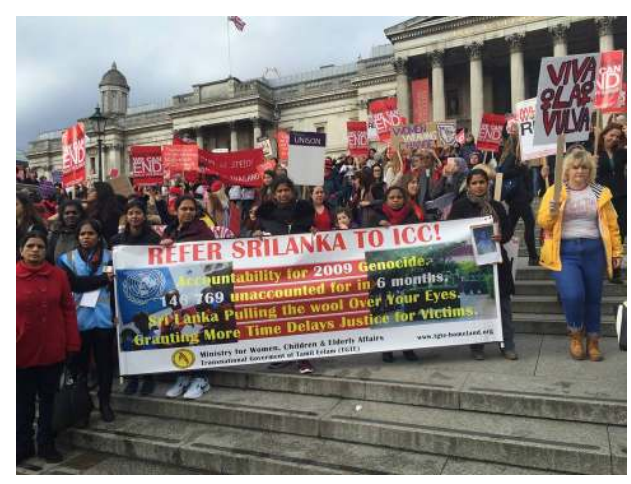
Association for South Asian Studies (BASAS), which should have taken place in Southampton in 2020. ${ }^{1}$ The outbreak of the COVID-19 pandemic disrupted some of these events and several of our prospective contributors had to withdraw from the Special Issue project, while others were variously impacted and impeded. Yet we are proud to have been able finally to channel the scholarly energies that fueled our theoretical and empirical conversations into this Special Issue, which, in our view, came together against many odds.

It is certainly a shorter Special Issue than we had hoped for, but we decided to take up the challenge of revisiting the question of the migrants' political mobilizations on the basis of the contributions we were able to gather. We turned it into an opportunity for thinking differently about our chosen object of study. This has led us to shift our attention to a specific type of migrant-migrants who may or may not be refugees, ${ }^{2}$ but who have in common the fact of having been the victims of either political (Tibetans or 
Sri Lankan Tamils in this Special Issue) or social (Dalits in this Special Issue) oppression in the country of origin.

3 In a previous Special Issue of SAMAJ, co-editors Mohammad-Arif and Moliner focused on "Inter-Communal Relationships amongst South Asian Diasporas" (SAMAJ 2007). In their study of diasporic constructions of the Self and the Other, they concluded that, as a result of the migration process, "many ... immigrants experience a redefinition of their identities, some identities may become subsumed (like language or caste-based) while others may be given a new salience, and even take precedence over other identities (like religion), which is likely to have implications on inter-ethnic relationships" (SAMAJ 2007). It is another aspect of the transformation of migrants' identities abroad that this Special Issue seeks to address, by foregrounding the migrants' broader political engagement in the host country. In this issue, we will examine the ways in which a political struggle embraced by (mostly victim) migrants to change the situation at home (the homeland cause) undergoes transformations in contact with the political environment found in the host country. We will also analyze how the political mobilizations and loyalties of (victim) migrants evolve and how the migrants' transnational engagement can be associated with other political engagements in the host country.

\section{Political Mobilizations of South Asian Migrant Communities}

4 South Asian migrant communities, some of which are commonly referred to as diasporas, are diverse, numerous and widespread. This is the result of different waves of migration. One can recall, among others, the merchants and pilgrims of precolonial times who spread throughout the Indian Ocean, East Africa and South East Asia; the free migrants and indentured laborers moving to other countries of the British Empire during the colonial era; and, in the postcolonial period, skilled migrants settling down in Europe (especially the United Kingdom), North America and Australasia, as well as unskilled migrants leaving for the Middle East. If the destinations and the people involved have evolved over time, the pace of migration itself, although including some ups and downs, has remained both significant and steady. As a result, if we accept a wide-ranging definition of South Asia, as we do here-i.e. including migrants from India, Pakistan, Bangladesh, Sri Lanka, Myanmar, Afghanistan, Nepal, Bhutan and Tibet $^{3}$-South Asians abroad form the biggest migrant communities in the world, comprising more than 40 million people. ${ }^{4}$

South Asian migrants are also some of the most politicized migrants in the world. Their mobilizations can be centered on the political affairs of the homeland or revolve around issues that have appeared in their host country-much like the mobilizations of migrants from other regions of the world. There is an array of examples to choose from in the past decades. Let us recall here the support extended by some South Asian migrants to the Black Lives Matter (BLM) movement; the engagement of Sikh, Tibetan and Sri Lankan Tamil migrants for the nationalist struggles dedicated to the liberation of, respectively, Khalistan, Tibet and Tamil Eelam; the struggles against caste discrimination by Dalits and Ambedkarites abroad; the support extended to the Hindutva movement by some sections of the Hindu diaspora; the mobilization of the Sikh community in Canada and the United Kingdom for the recognition of cultural 
rights; and the engagement of transnational Hindutva networks in support of Trump or in the campaign for Brexit.

\section{Presentation of the Articles and Interviews}

6 This Special Issue, which consists of three articles and two interviews, aims at completing and developing this list. Lola Guyot's article investigates Sri Lankan Tamils, who form one of the most politically active diasporas in the world. Their mobilizations, both during and after the war (1982-2009), have been widely studied (e.g. Amarasingam 2015; Brun and Van Hear 2012; Dequirez 2011; Fuglerud 1999; Orjuela 2018, 2020), but scholars have focused almost exclusively on the transnational engagement of Sri Lankan Tamil migrants in favor of a separate Tamil state in Sri Lanka. Guyot offers us a fresh perspective on an already well-researched community by looking at an under-studied aspect of Sri Lankan Tamil political mobilizations abroad: how tensions in the Sri Lankan Tamil diaspora around the issue of incorporation in host-country politics have unfolded in three countries hosting diaspora activists, i.e. the United Kingdom, France and Canada. Anne-Sophie Bentz presents an innovative ethnography on the Tibetans' recent involvement in the local politics of Toronto after a life as Tibetan activists. This is a valuable addition to the rather short list of studies dedicated to the political mobilization of Tibetans in exile, most of which focus on the government-in-exile (e.g. Kauffmann 2015; McConnell 2016; see also Hess 2009 for a study on Tibetan activism in the United States).

7 Nicolas Jaoul explores how Ambedkarism, a movement started in the 1940s whose purpose was to abolish the caste system in India, transformed into a struggle against caste in the United Kingdom. There are numerous studies on Ambedkarism in India (e.g. Hardtmann 2009; Jaoul 2016; Joshi 1986; Juergensmeyer 1982; Mendelsohn and Vicziani 1998; Rao 2009), but very few researchers have focused on Ambedkarism outside India or on Dalits in the United Kingdom (Dhanda 2013; Nesbitt 2010; Takhar 2017). Jaoul presents us with a larger view on Dalit communities in the United Kingdom, which also covers more than half a century of Dalit and Ambedkarite mobilizations. His interview of scholar and activist Meena Dhanda aptly completes his article by examining the denial of caste's presence amidst British Punjabi Dalits.

Anouck Carsignol's interview of Canadian-based playwright and activist Rahul Varma aims at better understanding the multi-layered mobilization of South Asian activists in Canada. His personal journey as a Canadian of Indian origin, his artistic production as a ground-breaking playwright and his active mobilization in favor of social justice, pluralism and gender equity all inform his militant narrative encompassing the homeland, the country of adoption and other communities. ${ }^{5}$

\section{Transnational Practices and Political Integration in the Host Country}

There have been numerous studies devoted to the migrants' socio-economic and cultural integration in the host countries. This is true for South Asian migrant communities as well (Bacon 1996; Brown 2006; Bhatia 2007). There have also been numerous studies on the formation and maintenance of diasporic bonds. Here again 
South Asian migrant communities are no exception (Chatterji and Washbrook 2013; Koshy and Radakrishnan 2008; Van der Veer 1995; Vertovec 1997). The literature on the migrants' political experience is also abundant, including on some South Asian communities, such as Sri Lankan Tamils, Sikhs or Hindus. However, most scholars tend to work on only one aspect of the migrants' political engagement, thereby often overlooking the connections existing between various realms of mobilizations-which we will refer to as "diaspora politics," "immigrant politics" and "political participation."

\section{“Diaspora Politics," "Immigrant Politics" and "Political Participation"}

10 Scholars working on "diaspora politics" (aka "homeland politics") are interested in the engagement of migrants (and their descendants) in the political affairs of the homeland. They tackle issues such as the migrants' influence on the host country's foreign policy towards the homeland through ethnic lobbying, the diaspora's impact on the conflict at home (radicalization or pacification), the political mechanisms set up by sending states to mobilize or discipline the overseas population, as well as distance voting and the development of a political opposition in exile (e.g. Betts and Jones 2016; Dufoix 2002; Lyons and Mandaville 2012; Ragazzi 2014; Shain 1999; Sheffer 2003). Some of them initially considered, in line with Benedict Anderson's theorization of "longdistance nationalism," that migrants' transnational mobilizations are a specific phenomenon resulting from the experience of migration. This approach is now partly outdated. Numerous scholars, such as Østergaard-Nielsen (2003), Massicard (2005), Sökefeld (2006), Grojean (2008), Adamson (2012) or Steinhilper (2018), treat the migrants' transnational political engagement as a form of collective action obeying the same kind of mechanisms as other social movements. This has resulted in a new focus on resource mobilization, framing processes, political entrepreneurs and opportunity structures, in order to examine the migrant's trajectories of engagement with and disengagement from the homeland.

11 Scholars working on "immigrant politics" focus on the political actions undertaken to improve the migrants' own social, economic or legal situation in the host country. They are known for their studies of the struggles of undocumented migrants, mobilizations against racial discriminations or migrant workers' movements (e.g. Garbaye 2005; Koopmans 2004; Nicholls 2013, 2019; Siméant 1998). All these endeavors may be regarded as a particular aspect of the migrants' political participation in the host country-something we refer to as "political participation." They have, however, been considered so specific as to deserve special treatment. Scholars working on "political participation" concentrate on the migrants' political participation in the host country's mainstream politics. Their research deals mostly with immigrants' voting behaviors, but some of their studies also include less conventional forms of political participation, like involvement in social movements or civil society associations (e.g. Gabrielli, Gsir, and Zapata-Barrero 2017; Però and Solomos 2010; Morales and Giugni 2011).

The literature on the political mobilization of migrants is thus divided into three separate fields of research, the importance of which varies depending on the migrant communities under study. For instance, while the literature on the political aspects of South Asian diasporas is both rich and diverse, the focus usually is on transnational engagements oriented towards the country of origin, i.e. on "diaspora politics." This 
can be explained by the fact that several South Asian diasporas are actively engaged in the political affairs of the home country: Sikhs, Tibetans and Sri Lankan Tamils have even been treated as paradigmatic cases of "long distance nationalism." If political refugees are almost expected to defend the homeland cause, it should not be forgotten that other migrants and descendants of migrants also engage in "diaspora politics." In South Asia, an example of this would be the support provided by sections of the Hindu community abroad to the Hindutva movement in India.

13 As a result of this division into three separate fields of research, including in the case of South Asian migrants, scholars have largely ignored the connections between the various aspects of the migrants' political experience-such as, notably, the articulation between political mobilization towards the homeland and a broader participation of migrants in the political affairs of the host country. A few exceptions include the works of Østergaard-Nielsen (2003), Morales and Morariu (2011), Portes (1999; 2006; 2008), Gabrielli (2017) and Zederman (2018).

Questioning the nature of the different political engagements that migrants can undertake in the realms of "diaspora politics," "immigrant politics" and "political participation" amounts to questioning the relation between the migrants' transnational practices and the migrants' "political integration" in the host country. Are transnational political engagements a vector for or an impediment to the migrants' political integration in the host country? This question will serve as a guideline to our analysis.

\section{"Political Integration" as Process}

15 The migrants' "political integration" is usually considered a two-way process that refers to a combination of dynamics coming from the host country, i.e. the provision of political rights and opportunities to immigrants, and from the migrants themselves, i.e. an identification with the host society, a socialization to the political norms and values of the host country and a participation in its political affairs (Bauböck et al. 2006; Hellgren 2015; Penninx and Garcés-Mascareñas 2016). In the contributions to this Special Issue, what "political integration" entails varies slightly from one author to the next, which comes into view in the use of a different vocabulary. While Bentz refers to "political integration" in the commonly-used way presented above, Guyot uses "political inclusion" to better underline the modalities of migrants' assertion as political agents in the country of settlement. For they contribute to the political evolution of their host society just as much as the host society influences their own political trajectory. Adopting a subaltern view, Jaoul prefers "political emancipation," to insist on "the ability to make one's political voice heard and taken into consideration even while speaking from the margins." The different use of vocabulary should not, however, hide the fact that the authors all analyze a similar active endeavor on the migrants' part, thereby asserting the migrants' status as fully-fledged political actors in the host countries.

16 Scholars are not always keen to specify whether "diaspora politics" and "immigrant politics" should be regarded as part of a greater logic of "political integration" and therefore added to "political participation," which, by involving the participation of migrants to mainstream politics, clearly is a-if not the-central component of "political integration." Yet the underlying assumption is often that "diaspora politics" 
do not help much with "political integration" (the two being regularly portrayed as antithetical), while "immigrant politics" would be a first, though incomplete, move towards "political integration."

17 A commonly held view, in line with assimilationist perspectives, is that a transnational political engagement is an obstacle to the migrants' political integration. In its most extreme form, present in extreme-right discourses, this approach invites suspicions of a lack of allegiance to the country of residence and the specter of a fifth column. While some scholars have shared this view (e.g. Berger, Galonska, and Koopmans 2004; Cain and Doherty 2006; Huntington 2004; Staton, Jackson, and Canache 2007), such an approach has since been challenged by migration specialists who believe: 1) that transnational political activities oriented towards the home country and political integration in the host country are compatible (Basch, Glick Schiller, and SzantonBlanc 1994; Levitt 2001; Morawska 2003); or even 2) that transnational practices can foster the migrants' engagement in host-country politics (Gershon and Pantoja 2014; Guarnizo, Portes, and Haller 2003; Morales and Morariu 2011; Portes, Escobar, and Arana 2008; Portes and Rumbaut 2006; Zederman 2018). The main ideas developed by these researchers vary. For some, political skills and resources are transferable and transnationally-engaged migrants possess a higher mobilizing capacity (Morales and Morariu 2011); for others, activities oriented towards the home country increase the level of migrant political awareness, and, as such, can be regarded as a first step in a migrant's integration process (Portes 1999).

A number of authors have indeed come to consider political integration as a somewhat linear process, both in terms of modes of action and focus of mobilization. Two main phases of political engagement for migrants are postulated: 1) a civic phase, during which the migrants' political mobilization takes the form of protests, demonstrations, sit-ins, political strikes, hunger strikes, civil disobedience and boycotts; and 2) a political phase, during which migrants are able to vote or run for elections, to vote on referenda, to become members of political parties, to sit on advisory councils or contribute to other arenas of political dialogue (DeSipio 2011; Gabrielli et al. 2017). Some scholars also argue that it is not only the means available and, therefore, the forms of participation that change, but the migrants' focus. With time, migrant activism is said to evolve from "diaspora politics" to "immigrant politics" (Lacroix 2005; Østergaard-Nielsen 2003; Zederman 2018), and later still, to "political participation" (Garbaye 2005). The idea is that, as they gradually integrate socially and culturally in their country of residence, their political claims progressively shift from the situation in their home country, to their own situation as a group of migrants and then to political concerns that go beyond their status as migrants. It is further thought that, through this process, migrants become fully-fledged political actors in the countries of residence.

\section{Context(s) of Mobilization}

19 This leads us to the context of mobilization, which has long been one of the main concerns for Social Movement Studies scholars. They invite us to reflect on the way the political and institutional structure of the state impacts mobilizations. The first models developed, known as Political Opportunity Structure, posited that changing political opportunities are the primary factor of the growth and structuring of social movements (e.g. Eisinger 1973; McAdam 1982; Tarrow 1989; Tilly 1978). This is most 
important for us here as, given the new direction that the Special Issue eventually took, the host countries under consideration, i.e. Canada, the United Kingdom and France, are all Western countries. Due to the political and institutional structure of the state, the possibilities offered to migrants there, especially compared to the opportunities that the same migrants have in most South Asian countries, are huge-albeit slightly different from one Western country to another. We therefore need to keep in mind that, in the examples retained here, the opportunities for migrants to mobilize in any of the three realms, i.e. "diaspora politics," "immigrant politics" and "political participation," are significant.

If the host country is the main context of mobilization, there are other contexts that matter for migrant mobilization, such as, most notably, the home country. Fligstein and McAdam consider that "there are several different fields, all embedded in complex webs of other fields, in which players interact" (2012:18-19). This idea of different contexts where migrants do not just evolve, but interact with each other, is useful for our theoretical discussion. Not only does it refine the context(s) of mobilization, it also introduces the concept of relationality. The contexts would mean nothing without the actors involved. This idea of reclaiming agency for the migrant activists is at the heart of all contributions to this Special Issue. Thus, following Jasper's metaphor of mobilization as game (Jasper and Duyvendak 2015), we argue that what is needed on the migrant activists' part is a willingness to play the game.

\section{Tackling the Migrants' Multifaceted Political Engagements}

This Special Issue brings forth a reflection on the links between "diaspora politics," "immigrant politics" and "political participation" and on the question of the migrants' "political integration," both of which, as we have pointed out, are understudied aspects of South Asian (and other) migrants' mobilizations.

We will look at how migrants themselves conceive the relations between various political engagements, highlighting in the process the debates that might exist within a diasporic field about the reasons for mobilizing or the nature of the mobilizations undertaken. How are processes of collective identification affected by the engagement of activists in several political spheres? Do they consider their mobilizations in the realms of "diaspora politics," "immigrant politics" and "political participation" in the host country as distinct, potentially antithetical, political endeavors or as complementary intermingled struggles? Can mobilization for the homeland cause ("diaspora politics") have repercussions on the other struggles fought ("immigrant politics" or "political participation")? And is there a process of hierarchization when activists embrace multiple causes? We will also study the social trajectories and processes of identification of migrant activists, focusing specifically on the generation factor. Are, as one might expect, first generation migrants engaged in transnational struggles, while descendants of migrants prefer mobilizing for causes relating to the country of settlement? This comes down to asking whether specific social and cultural capitals are associated with different spheres of migrant activism.

The main goals of this Special Issue are: 1) to analyze the relations between "diaspora politics," "immigrant politics" and "political participation" and 2) to look at the impact 
of the migrants' multifaceted political engagements on "political integration" in the host country. We will thus shed light on an aspect of South Asian migrant mobilization that is overlooked in the existing literature on South Asian diasporas. And we will draw on cases of South Asian migrant mobilizations to contribute to the broader theoretical debate on the links between transnational mobilization and the migrants' political integration in the countries of settlement.

It should be noted that since the focus of this Special Issue is on the political mobilizations of migrants, the primary objects/subjects of study are political activists and not diaspora members at large. However, the fact that the migrants under consideration have been the victims of political or social oppression in the home country can account for a higher degree of mobilization among diaspora members than is usually the case. What is more, diasporas derived from minority ethnic groups with a history of national liberation struggle are commonly considered as the most politically active diasporas, with numerous activists engaged in opposition politics in exile. The strength of their sentiment towards the homeland, i.e. their "degree of diasporacity," is high, implying attitudes and behaviors such as "influencing a hostland government to pursue policies favorable to the homeland; ... going off to fight for the homeland; preparing to return to the homeland" (Safran 1999). This is not to say that all diasporas under consideration here are "victim diasporas" (Cohen 1997) or that all members of the diaspora are "victims," but that such migrants are, to use Christie's expression, "ideal migrant victims," i.e. individuals who are considered more deserving of victim status than others (Furusho 2018). They may refer to this vulnerability as they see fitwhen some emphasize it, others choose to deem it less relevant (Furusho 2018). They may also find it challenging to simultaneously have their suffering recognized and not be confined to a victim status (Smets et al. 2019). It is therefore interesting to see how victimization is perceived, deconstructed and negotiated. In any case, political activists can use, and have successfully used, the vulnerability associated with "victim diasporas" and "victim migrants" as a leverage tool for mobilization.

However, politically active migrants cannot all be, or pretend to be, the victims of oppression, just as the political cause for which migrants mobilize abroad is not necessarily a national liberation cause directed against the home government. True, this is the case for most South Asian diasporic mobilizations, prime examples of which include the Sikhs, the Kashmiris, the Sri Lankan Tamils and the Tibetans. But mobilizations in support of the home government also exist, as shown by Hindutva activists abroad while the Bharatiya Janata Party (BJP) is in power in India. While the contributions to this Special Issue all focus on migrants who have been the victims of oppression in the country of origin, and therefore on activists opposed to the home government, we believe that some of the conclusions presented in the following discussion remain valid for diasporic political mobilizations generally.

We start our discussion with a presentation of the homeland cause, specifically highlighting the role played by political entrepreneurs at home or in the diaspora to secure the migrants' support. Not only is a clearly defined homeland cause often the first and most important issue around which (victim) migrants mobilize, the cause brought from the homeland usually continues to define the political life of both migrants and descendants of migrants for a long time. While focusing first on "diaspora politics," we show that the primacy of the homeland cause can, but does not necessarily preclude, other forms of political engagement, notably in the sphere of "immigrant 
politics." We study in detail one such example-politics of recognition. This leads us to analyze the compatibility of the migrant's different types of political engagements, all the while looking at the possible obstacles to the migrant's political (and sometimes also socio-economic) integration in the countries of settlement. We then investigate the evolving strategies deployed by political entrepreneurs, looking notably at how the homeland cause is adapted to better take into account new situations in the homeland or in the countries of settlement. Of specific interest to us is the impact that such an adaptation has on the migrant's political engagement in the three spheres ("diaspora politics," "immigrant politics" and "political participation"). We conclude with the migrant's formal involvement in local and national politics, which is often seen as the high point of the migrant's political integration in the host country. We emphasize here the extent to which, in the cases under consideration, the homeland cause still features quite high on the agenda, pointing to a continuing overlap of "diaspora politics" and "political participation."

\section{The Primacy of the Homeland Cause}

Some migrants, such as the Tibetans, the Sri Lankan Tamils or the Burmese went into exile when the conflict at home had already started. When they went abroad, they went as refugees. It does not matter for our argument whether they had secured refugee status before leaving or whether they sought refugee status once they arrived. What matters is that, presenting themselves as refugees, they were bringing with them the very reason that had made them leave in the first place-conflict at home. In other words, they were, willingly or not, bringing with them a (quite) clearly defined issue from home-the cause of Tibet, the liberation of Tamil Eelam or the fight for democracy in Myanmar.

In other cases, migrants did not leave the home country with an already defined cause, but came to develop a homeland cause abroad, sometimes after several years or even decades (e.g. Féron and Lefort 2019). Second- or third-generation migrants then play a significant role in the definition of the cause. For example, it is not until Operation Bluestar, which led to the desecration of the Golden Temple in 1984, that the Sikh community abroad started to engage in nationalist politics. This event, which was followed by anti-Sikh riots in India, is said to have worked as a "critical event" (Tatla 1999), leading many Sikhs abroad to develop a sense of collective identity and to look back to the ancestral homeland-aptly renamed Khalistan. The "birth" of the Sikhs as a diaspora therefore went hand in hand with mobilization for the Khalistani cause (Gunawardena 2001). The Kashmiri diaspora, whose members mostly come from Azad Kashmir (Pakistan), did not emerge as a direct consequence of migration, but developed in the mid-1980s as a result of the insurgency in Jammu and Kashmir (India) (Ellis and Khan 1998; Sökefeld 2006). The insurgency led to the assertion of a distinctive Kashmiri solidarity that transcended the division of the region between Pakistan and India and defended the nationalist idea of Kashmiriyat [Kashmiri-ness] (Ali 2003).

We argue that the development of a strong sense of collective identity around a homeland cause is precipitated by what Betts and Jones (2016) refer to as "diasporic moments" occurring either right at the beginning of exile or at a later stage, usually following a key and often traumatic event in the homeland. ${ }^{6}$ The causes embraced vary. They include 1) fighting for what the migrants see as an endangered homeland, i.e. 
pushing for democracy and/or federalism (Burmese) or engaging in a nationalist/ separatist struggle, either by taking up arms (Sri Lankan Tamils, Sikhs and Kashmiris) or by embracing non-violence (Tibetans), and 2) engaging in a social justice struggle (Dalits).

While the causes vary, however, what does not vary is that it is not spontaneously, but through the impulsion of political actors based at home or in the diaspora, that migrants embrace a political cause whose first (and often only) aim is to transform the situation in the home country.

\section{Political Entrepreneurs}

It is through the establishment of movements, associations or organizations that political entrepreneurs undertake to make migrants and descendants of migrants start or continue to mobilize for a cause. The cause may thus become a way to promote and preserve the group's identity. However, if it unites the migrants, and thereby ensures the survival of the community, it also imprisons the community within the vision of the dominant political entrepreneurs. ${ }^{7}$

The nature of the links between political actors, at home and in the diaspora, and the strategies adopted by diaspora activists to promote the cause, have a lot to do with the assumed compatibility of homeland-oriented activism with other forms of political engagement abroad. Diasporic engagement in favor of the homeland seems to be the prime struggle when dominant diasporic actors are subordinated to homeland actors. Examples include diaspora-based student organizations, such as the All-Burma Students Front (ABSDF) and the All Burma Students' League (ABSL), as well as the National Coalition Government of Burma (NCGUB) aligning with pro-democracy movements in Myanmar (Bentz 2022; Oo 2006; Williams 2012); the national Tamil Coordination Committees (TCCs), which supervised a vast network of local associations for Sri Lankan Tamil migrants, working under the auspices of the Tamil Tigers; the Hindu Swayamsevak Sangh (HSS), or Hindu Volunteers Corps, subordinated to the Rashtriya Swayamsevak Sangh (RSS); and, in the case of Dalits, the Republican Group of Great Britain (RGGB) supporting the Republican Party of India (RPI). Or, more rarely, when dominant diasporic actors become the main homeland actors-e.g. the Jammu Kashmir Liberation Front (JKLF), founded in the United Kingdom, but relocated to Kashmir (both India and Pakistan) in the 1980s (Adamson 2016). Bringing support to the central organization in the homeland is then a major part of the diasporic organizations' activities.

When dominant diasporic actors are independent from homeland actors, the homeland cause can still be central, but bringing support to actors at home is less of a priority. This is the case, most notably, for Tibetan organizations abroad, such as the Tibetan Youth Congress (TYC), the Tibetan Women Association (TWA) or Students for a Free Tibet (SFT), which support the cause of Tibet, but are not active in Tibet proper, where homeland actors are too few and too weak to offer an effective mobilization against Chinese rule. In other cases where diasporic actors are independent from homeland actors, the focus on the homeland is often gradually lost. Pro-Khalistani mobilizations abroad are interesting in this regard. Although many diasporic organizations supported insurgents in Punjab with funding, and sometimes combatants, most attempts at establishing a sustained collaboration during the conflict failed 
(Gayer 2000; Tatla 1999). The "solidarist fiction" (Gayer 2000) therefore disappeared at the end of the conflict, leaving diasporic organizations free to handle the struggle for Khalistan in the international arena.

\section{Promotion of the Cause vs. Political Integration in the Host Country}

The primacy given to the cause can have far-reaching consequences, for instance when other types of political engagement are rejected. Tamil Tigers saw not just political integration, but socio-cultural integration in the host countries as potentially conducive to demobilization. This led them to encourage Sri Lankan Tamil migrants to refrain from engaging in host-country politics and, given that they had a monopoly on diasporic organizations, such a strategy worked quite well as long as the war lasted. This strategy has been used by other national liberation movements, such as the National Liberation Front (FLN) in Algeria and the Kurdistan Workers' Party (PKK) in Turkey, both of which established diasporic structures promoting at some point the idea that the struggle at home prevailed and that migrants should be precluded from any other form of political engagement. The instruction given to Tibetan refugees in India and Nepal not to take on citizenship can be interpreted along the same lines. In an effort to remain apart from the wider society, what the Central Tibetan Administration (CTA) is in fact doing is bringing forward the collective identity of a group, Tibetan refugees, fighting for a cause-the cause of Tibet.

If, in some cases, the primacy of the cause precludes other types of mobilization, and therefore the integration of migrants in the host countries, in many other cases, migrants are encouraged to adapt to the host-country environment. The assumed compatibility of homeland-oriented activism with other forms of political engagement abroad explains, for instance, the Dalits' early implication in the defense of workers' rights through trade unions. The same could be said for the Sikhs. They had already been politically integrated in the countries of settlement when they were mobilized around the cause for Khalistan. Political entrepreneurs did not ask them to renounce all previous political engagements, only to (re)focus on the fight for their (newly) endangered homeland.

It appears that transnational political engagements, when centered around a homeland cause, can, in limited cases and for a limited period of time, be an impediment to the migrants' political integration in the host country. We argue that, after a while and often following a key event in the homeland, migrants' mobilizations undergo a reconfiguration whereby activists start to see things differently regarding both the primacy of the cause and political integration in the host countries. This usually implies a change of strategy, whereby (both old and new) diasporic organizations accept, or even favor, other types of political engagements on the migrants' part.

The key event for Sri Lankan Tamils was the end of the war (and the defeat of the Tamil Tigers) in 2009. The independent lobbying groups that emerged no longer fought the regime in Sri Lanka, but focused on obtaining international support and perpetuating a commitment of the diaspora to the Tamil cause. The Tibetans' moment was the beginning of further diasporization in the 1990s: this was the right time for the Central Tibetan Administration (CTA) to try out a new strategy. In South Asia, where Tibetans first took refuge, it was thought that living in dedicated settlements and concentrating on preserving Tibetan culture, while letting the Dalai Lama gather international 
support, was the best way to promote the cause of Tibet. By contrast, in North America, the promotion of the cause was meant to be realized through the Tibetans' active engagement on the host-country political scene-i.e. through political integration. Interestingly, there is no obvious strategic adaptation in the Sikh case, mainly because pro-Khalistani organizations abroad have been mostly active on the international scene (and not in Punjab), both during and after the insurgency. They have highlighted the plight of the Sikh community under India's "Brahmin Hindu rule" and asked the international community, and their host states, to exert pressure on New Delhi to stop suppressing the movement for Khalistan (Kumar 2008).

These cases show that dominant political entrepreneurs may eventually welcome a more diverse set of strategies to support the cause that involves a better integration in the host country for migrants-one such example is politics of recognition.

\section{Politics of Recognition}

Migrants coming from minority groups persecuted in the homeland may demand to be recognized as distinct cultural, ethnic or even national groups in the receiving states. This is a way to ask for specific cultural rights in the host countries, but it also sends a strong signal to the homeland regime (Østergaard-Nielsen 2003). As noted by Guyot, after the war, "[the international arena] had become a space where [Sri Lankan] Tamils could freely formulate a counter-narrative forbidden in the homeland." This is why it had become all the more important to obtain expressions of symbolic recognition. The same could be said of the Tibetans who started fleeing to neighboring countries after the resistance in Tibet was crushed in 1959. Or of Sikhs from the 1980s onwards. This is when they sought recognition of their status as a distinct nation and actively promoted their own memory of the struggle, in order to propagate their ethnonational heritage and to challenge the image of Sikhs as "terrorists" (Kumar 2008).

Examples of politics of recognition ${ }^{8}$ include lobbying the host country to have a month dedicated to promoting the homeland culture: during the 2010s and early 2020s, January, April, July and November were proclaimed, respectively, "Tamil Heritage Month," "Sikh Heritage Month," "Tibetan Heritage Month" and "Hindu Heritage Month" in either Ontario or Canada. These examples show that Sikh, Sri Lankan Tamil and Tibetan activists, much like Kurdish activists (Østergaard-Nielsen 2003), mix "immigrant politics" with "diaspora politics" when adapting the demands to support the cause.

Moreover, through recognition politics, "diaspora politics" can be a leverage tool for migrants in "immigrant politics." This happens when their homeland-oriented nationalist engagement enables them to ask for equality of treatment and/or cultural rights in their country of settlement. The best examples of this strategy are the mobilizations led by Punjabi migrants within the Ghadar and Khalistani movements (Dusenbery 1995; Gayer 2000; Juergensmeyer 1997). The Ghadar movement was founded in the early $20^{\text {th }}$ century to overthrow British rule in India and challenge processes of racial segregation in North America (Dusenbery 1995). Fighting to liberate the subcontinent was seen as a way to improve the plight of migrants overseas. Initially triggered by a feeling of sympathy for persecuted compatriots in the homeland, mobilization for Khalistan abroad was also seen as a way to engage in politics of cultural recognition, including demands for the right to wear the turban and the kirpan 
[dagger] at all times, the promotion of the Punjabi language in schools or the inclusion of a separate category for Sikhs in national censuses. In a multiculturalist context, where bargaining for resources among ethnic groups almost "requires" a recognized homeland for migrant groups, "Khalistan supporters in the diaspora can be seen to gain a measure of respect and power in countries of the diaspora by changing the contemporary political map of South Asia" (Dusenbery 1995:34). Such an instrumentalization of the cause prompts Gayer (2000) to prefer Appadurai's “Trojan nationalism" over Anderson's "long-distance nationalism" to describe Khalistan activists abroad. Another example of the double use of politics of recognition is the mobilization led by Kashmiri migrants in the late 1990s for the formal recognition of Kashmiris as a distinct ethnic minority in the United Kingdom (Ali 2003:477-78). They did so to have better access to measures devised to help underprivileged minorities, but, in the context of the insurgency in Jammu and Kashmir, it was also regarded as an important step in the mobilization for the Kashmiri cause (Sökefeld and Bolognani 2011).

Efforts by Hindu nationalist organizations in the West to promote Hindutva ideology, such as attempts to alter the school curriculum on Hinduism and ancient India (Bose 2008), can similarly be understood as endeavors at the crossroads of "diaspora politics" and "immigrant politics." The objective of this type of recognition lobbying is arguably as much to attract international allies to the Hindutva cause as to instigate a sense of pride amongst Hindu migrants.

We therefore argue that politics of recognition provide the perfect example of political engagements belonging simultaneously to "diaspora politics" and "immigrant politics." This is possible because politics of recognition do not imply an abandonment of the primacy of the cause.

\section{Adaptation of the Cause?}

44 If a change of strategy does not stop the cause from still featuring high on the agenda of diasporic organizations, the formulation of the cause, if not the cause itself, may sometimes be slightly adapted. Such strategic framing has been used by many diasporic organizations that have come to realize that asking for the support of a national liberation struggle is contrary to the international norms promoted by the host country. Even asking for the support of a non-violent struggle may be too much of a stretch. Most Tibetans, who had been asking for full independence using the people's right to self-determination argument, tried out a new discourse by putting human rights violations (from the 1980s onwards) and environmental concerns (in the 1990s) first. After the war, independent diasporic organizations started reframing the Sri Lankan Tamils' grievances in terms congruent with the more popular liberal norms of human rights, transitional justice and the promotion of democracy. A number of Sikh lobbyists found it useful from the 1990s onwards to downplay separatist demands for Khalistan and (re)focus on the human rights violations faced by the Sikhs in Punjab (Shani 2002).

We also argue that the Ambedkarites' reaction to the loss of influence brought about by the acceleration of "the dynamics of casteification of social life in British Indian localities" in the 1970s are renewed attempts at engaging the two fields of "immigrant politics" (to raise awareness about caste prejudice in the United Kingdom, something 
which culminated in the creation of Castewatch UK in 2003) and "diaspora politics" (to promote Ambedkarism in Punjab by focusing on Buddhist proselytism within the newly-founded Punjab Buddhist Society [PBS] UK). The homeland cause has become a transnational cause with new and localized dynamics. This is also to say that the (original) fight against caste in India and the (new) anti-caste struggle in the United Kingdom are two complementary intermingled struggles.

The cause, even when adapted, still features high on the agenda. The reason why it has not been forgotten or rejected is because it appears compatible with other political engagements. This is another way of saying that "diaspora politics" and "immigrant politics" are compatible, or can even reinforce each other, and that diasporic organizations have become aware of this dynamic and have reacted accordingly. It is also another way of saying that transnational political engagements can be a vector for the migrant's political integration in the host country.

\section{Involvement in Local and National Politics}

It is indeed often through an engagement in "diaspora politics" and "immigrant politics" that the migrant activist becomes a highly political subject who may at some point want to enter into local, and sometimes even national, politics ("political participation").

The institutional and political context here obviously plays a role. Some political systems are better suited for allowing migrants to engage in host-country politics beyond immigrant politics. This is notably the case in multiculturalist countries where links can more easily be established between diasporic organizations and political parties. These links may seem instrumental at first: migrant activists, especially among migrants who defend a homeland cause, may not align ideologically with any of the host-country's major parties, but will side with any party or leader supporting the cause. Tibetans in Canada have praised former Prime Minister Stephen Harper (Conservative Party) for making the Dalai Lama an honorary citizen of Canada in 2006 and criticized current Prime Minister Justin Trudeau (Liberal Party) for siding with China in 2013. Supporting political parties can also be seen as part of a lobbying strategy. The non-partisan British Tamils Forum (BTF) established two groups, Tamils for Labour and British Tamil Conservatives, with a view to rationalize lobbying efforts. British Kashmiris created the All-Party Parliamentary Group on Kashmir (APPGK) for the same purpose (Ellis and Khan 1998). Ideological affinities can also play a role: these links between diasporic organizations and political parties can thus be sought after by conservative and extreme-right groups eager to support host-country political actors sharing the same political orientation. Hindutva activists and Trump supporters share a common Islamophobic construction of the Muslim as Enemy. This ideological affinity explains the support brought by some Hindu nationalist organizations, such as Hindus for Trump, the Indian American Intellectual Forum (IAIF) and the Republican Hindu Coalition (RHC), to Donald Trump in the 2016 electoral campaign (Thobani 2019). Hindu symbols occupied an important place in this support, with havan pujas [fire rituals] staged to honor Donald Trump or activists brandishing portraits of Trump with a tilak [colored mark worn on the forehead]. include good prospects of acquiring citizenship swiftly, an easy access to social, 
economic and health benefits, as well as decent employment opportunities. All of these can be found in Canada, which explains why Sikh diasporic organizations in Canada have been quite successful in encouraging Sikh migrants to join host-country politics: there were 19 Canadian Sikhs (some of whom had a pro-Khalistan activist background) among the Members of Parliament (MPs) elected in the 2015 Canadian Federal Election, four of whom became Cabinet Ministers. Such a trajectory has been followed at the national level by Sri-Lankan Canadians Rathika Sitsabaiesan, former vice-president of the Tamil Student Association of Toronto, and Gary Anandasangaree, member of the Canadian Tamil Congress, and, at the provincial level (Toronto) by Tibetan-Canadian and incumbent Member of Provincial Parliament (MPP) Bhutila Karpoche. Conditions for participation in host-country politics also became particularly propitious for Kashmiris in the United Kingdom, leading to the election of hundreds of councilors, more than a dozen Mayors and Lord Mayors, six Members of Parliament (MPs) and three members in the House of Lords of Kashmiri origin, turning Kashmiris into one of the largest minority ethnic groups in terms of representation at all levels of the political system (Haroon 2018:160-62).

This is not to say that migrants cannot participate in host-country politics when the above-mentioned factors favoring participation are not found, only, to retain the concepts presented earlier, that the means available may prevent migrants from moving from "a civic phase" to "a political phase." This is what happens to many South Asian migrants who, in several Asian countries, do not have access to citizenship. They may be just as committed as their counterparts in Western countries, but differently so, having for instance recourse to what Holston has termed "insurgent citizenship practices" (e.g. Olivius 2019 for the Burmese in Thailand).

The question still remains as to whether "political participation" is a clear sign of the migrants' political integration in the host country, since migrants can sometimes engage in host-country politics mainly to promote the homeland cause. For instance, the first Dalit candidates fighting for election in the United Kingdom sought the investiture of the Republican Group of Great Britain (RGGB), thus branding themselves not as British citizens, but as local representatives of the Republican Party of India (RPI). Bishan Dass was elected in 1975 as a candidate of the Labour Party. Interestingly, he presents his involvement in the party as congruent with his Ambedkarite commitment, drawing a parallel between the urge to fight racism in the United Kingdom and the fight against caste in India. Such an overlap between "diaspora politics" and "political participation" is even stronger in the Sri Lankan Tamil case, where standing for elections was often presented as a way to promote the Tamil cause. Some candidates initially ran on two parallel programs aimed at, respectively, the Sri Lankan Tamil community and the rest of the constituency. This also happened to candidates from the Justice for Kashmir (JFK) group elected to serve on the Birmingham City Council in 2000 (Khan N.d.). The same has been said of Senator Moua and Representative Thao about the promotion of the Hmong cause in the United States (Hein and Vang 2015). And of Bhutila Karpoche in Toronto who, in Bentz's words, was fulfilling two roles at the same time, "the role of a politically integrated TibetanCanadian, as well as the role of 'ambassador' of Tibet." What these examples tend to show is that politicians with an ethnic background are expected to defend specifically ethnic causes pertaining to the homeland. "Political participation" can thus also be construed as a strategy to favor "diaspora politics." This being said, other political interests may sometimes also be at stake, and once migrants get elected, new priorities 
emerge. Their ethnic commitment may then be overshadowed by a need to focus on the political affairs of their host countries.

It should be noted that, as has been observed by scholars in other cases, candidates and elected politicians use the political resources and skills developed when activism was primarily directed towards the homeland cause. Our examples tend to prove that transnational political engagements produce political knowledge and, because of that at least, work as a vector for the migrants' political integration in the host country.

\section{Transnational Mobilizations and Political Integration as Compatible Processes}

53 We have shown in this introduction that the three spheres of the migrants' political engagement in the host country that are usually distinguished in the literature in reality often overlap. There are numerous examples of migrants getting involved simultaneously in "diaspora politics" and "immigrant politics"-even when the homeland cause features high on the migrants' agenda, as it does in the Sikh, Burmese, Tibetan, Sri Lankan Tamil and Kashmiri cases. This can happen right from the start (e.g. Tibetans and Dalits) or later on (e.g. Sri Lankan Tamils and Sikhs). Within the migrants' engagement in host-country politics, it is also difficult to clearly distinguish between a genuine interest in local politics (i.e. "political participation") or an instrumentalization of the host-country political game to favor the homeland cause (i.e., even if indirectly so, "diaspora politics"). The trajectories of some Sikh, Sri Lankan Tamil and Tibetan politicians illustrate this point quite well.

The links that we were able to establish between the three spheres of the migrants' political engagement in the host country further point to the futility of the idea of a three-phased linear process followed by migrants. Even if "diaspora politics" seems to be the first field invested by some of the migrants under study, most notably political refugees, such as Tibetans, Sri Lankan Tamils and Burmese, but also Palestinians; even if "political participation" can only happen at a later stage, when migrants are settled enough to become citizens in the host countries; in many cases migrants invest simultaneously at least two of the three fields, either "diaspora politics" and "immigrant politics" or "political participation" and "diaspora politics." This is why transnational mobilizations and political integration are perfectly compatible processes. In many cases, the two processes even seem to reinforce each other, by turning migrant activists into concerned citizens in the host countries (e.g. British Dalits or Tibetans in Canada). Much has been written about the political skills and resources developed in homeland-related activities, but the examples developed here tend to show that it is not just the means to participate in host-country politics that migrant activists acquire, it is more than that-the mindset of politically-engaged citizens. 


\section{BIBLIOGRAPHY}

Adamson, Fiona. 2012. "Constructing the Diaspora: Diaspora Identity Politics and Transnational Social Movements.” Pp. 25-42 in Politics from Afar: Transnational Diasporas and Networks, edited by T. Lyons and P. Mandaville. New York: Columbia University Press.

Adamson, Fiona. 2016. “The Growing Importance of Diaspora Politics.” Current History 115(784): 291-97.

Ali, Nasreen. 2003. "Diaspora and Nation: Displacement and the Politics of Kashmiri Identity in Britain.” Contemporary South Asia 12(4):471-80.

Amarasingam, Amarnath. 2015. Pain, Pride and Politics: Social Movement Activism and the Sri Lankan Tamil Diaspora in Canada. Athens, Georgia: The University of Georgia Press.

Bacon, Jean. 1996. Life Lines: Community, Family and Assimilation among Asian Indian Immigrants. New York: Oxford University Press.

Basch, Linda, Nina Glick Schiller and Cristina Szanton-Blanc. 1994. Nations Unbound: Transnational Projects and the Deterritorialized Nation-State. New York: Gordon and Breach.

Bauböck, Rainer, Albert Kraler, Marco Martiniello, and Bernhard Perchinig. 2006. “Migrants' Citizenship: Legal Status, Rights and Political Participation." Pp. 65-98 in The Dynamics of International Migration and Settlement in Europe, edited by R. Penninx, M. Berger and K. Kraal. Amsterdam: Amsterdam University Press.

Baumann, Gerd. 1998. "Body Politic or Bodies of Culture? How Nation-State Practices Turn Citizens into Religious Minorities.” Cultural Dynamics 10(3):263-80.

Bentz, Anne-Sophie. 2022. "Nationalism in Exile. Burmese and Tibetan Refugees in India." Pp. 8197 in Migration Governance in Asia, edited by K. Sakai and N. Lanna. Oxford: Routledge.

Berger, Maria, Christian Galonska, and Ruud Koopmans. 2004. "Political Integration by a Detour? Ethnic Communities and Social Capital of Migrants in Berlin." Journal of Ethnic and Migration Studies 30(3):491-507.

Betts, Alexander, and Will Jones. 2016. Mobilising the Diaspora: How Refugees Challenge Authoritarianism. Cambridge: Cambridge University Press.

Bhatia, Sunil. 2007. American Karma: Race, Culture and Identity in the South Asian Diaspora. New York: New York University Press.

Bose, Purnima. 2008. "Hindutva Abroad: The California Textbook Controversy." The Global South 2(1):11-34.

Brees, Inge. 2010. "Refugee and Transnationalism on the Thai-Burmese Border." Global Networks 10(2):282-99.

Brown, Judith M. 2006. Global South Asians: Introducing the Modern Diaspora. Cambridge: Cambridge University Press.

Brun, Catherine and Nicholas Van Hear. 2012. "Between the Local and the Diasporic: The Shifting Centre of Gravity in War-Torn Sri Lanka's Transnational Politics.” Contemporary South Asia 20(1): 61-75.

Cain, Bruce E., and Brendan J. Doherty. 2006. "The Impact of Dual Nationality on Political Participation.” Pp. 89-105 in Transforming Politics, Transforming America: The Political and Civic 
Incorporation of Immigrants in the United States, edited by T. Lee, S. K. Ramakrishnan, and R. Ramirez. Charlottesville: University of Virginia Press.

Carsignol, Anouck. 2022. "Diasporic Mobilizations and Inter-Community Solidarities: Negotiating South Asian Subjectivity and Positionality in Canada." DESI 5:19-47.

Chatterji, Joya and David Washbrook. 2013. Routledge Handbook of the South Asian Diaspora. $1^{\text {st }}$ ed. Oxfordshire: Routledge Handbooks.

Cohen, Robin. 1997. Global Diasporas: An Introduction. London: University College London Press.

Dequirez, Gaëlle. 2011. "Nationalisme à longue distance et mobilisations politiques en diaspora. Le Mouvement séparatiste tamoul sri-lankais en France (1980-2009).” PhD dissertation, Political Science, University of Lille II.

DeSipio, Louis. 2011. "Immigrant Incorporation in an Era of Weak Civic Institutions: Immigrant Civic and Political Participation in the United States." American Behavioral Scientist 55(9):1189-213.

Dhanda, Meena. 2013. "Caste and International Migration, India to the UK." In The Encyclopedia of Global Human Migration, edited by I. Ness. Malden: Wiley-Blackwell. Retrieved January 30, 2022 (https://doi.org/10.1002/9781444351071.wbeghm105).

Dufoix, Stéphane. 2002. Politiques d'exil. Hongrois, Polonais et Tchécoslovaques en France après 1945. Paris: Presses Universitaires de France.

Dusenbery, Verne A. 1995. “Chapter 1. A Sikh Diaspora? Contested Identities and Constructed Realities." Pp. 17-42 in Nation and Migration, edited by P. Van der Veer. Philadelphia: University of Pennsylvania Press.

Egreteau, Renaud. 2012. "Burma in Diaspora: A Preliminary Research Note on the Politics of Burmese Diasporic Communities in Asia." Journal of Current Southeast Asian Affairs 31(2):115-47.

Eisinger, Peter K. 1973. “The Conditions of Protest Behavior in American Cities.” American Political Science Review 67(1):11-28.

Ellis, Patricia and Zafar Khan. 1998. "Diasporic Mobilization and the Kashmir Issue in British Politics." Journal of Ethnic and Migration Studies 24(3):471-88.

Féron, Elise and Bruno Lefort. 2019. "Diasporas and Conflicts: Understanding the Nexus." Diaspora Studies 12(1):34-51.

Fligstein, Neil, and Doug McAdam. 2012. A Theory of Fields. Oxford: Oxford University Press.

Fuglerud, Øivind. 1999. Life on the Outside: The Tamil Diaspora and Long-distance Nationalism. London: Pluto Press.

Furusho, Carolina Yoko. 2018. “The 'Ideal Migrant Victim' in Human Rights Courts: Between Vulnerability and Otherness." Pp. 123-40 in Revisiting the "Ideal Victim": Developments in Critical Victimology, edited by M. Duggan. Bristol: Bristol University Press.

Gabrielli, Lorenzo, Sonia Gsir, and Ricard Zapata-Barrero. 2017. "Political and Civic Participation of Immigrants in Host Countries: An Interpretative Framework from the Perspective of the Origin Countries and Societies." Pp. 87-116 in Migrant Integration between Homeland and Host Society, edited by A. Weinar, A. Unterreiner and P. Fargues. Berlin: Springer.

Garbaye, Romain. 2005. Getting into Local Power: The Politics of Ethnic Minorities in British and French Cities. Oxford: Blackwell.

Gayer, Laurent. 2000. “The Globalisation of Identity Politics: The Sikh Experience.” International Journal of Punjab Studies 7:223-62. 
Gershon, Sarah A., and Adrian D. Pantoja. 2014. "Pessimists, Optimists, and Skeptics: The Consequences of Transnational Ties for Latino Immigrant Naturalization." Social Science Quarterly 95(2):328-42.

Grojean, Olivier. 2008. "La Cause kurde, de la Turquie vers l'Europe. Contribution à une sociologie de la transnationalisation des mobilisations." PhD dissertation, Political Science, EHESS.

Guarnizo, Luis E., Alejandro Portes, and William J. Haller. 2003. “Assimilation and Transnationalism: Determinants of Transnational Political Action among Contemporary Immigrants." American Journal of Sociology 108(6):1211-48.

Gunawardena, Therese S. 2001. Contesting Khalistan: The Sikh Diaspora and the Politics of Separatism. PhD dissertation, Philosophy Department, University of Texas at Austin.

Hardtmann, Eva-Maria. 2009. The Dalit Movement in India: Local Practice and Global Connections in the Dalit Movement. New Delhi: Oxford University Press.

Haroon, Lubna. 2018. “The Role of Kashmiri Diaspora in Conflict Transformation.” Journal of Political Studies 25(1):157-67.

Hein, Jeremy, and Nengher Vang. 2015. "Politicians and Social Movements: The Impact of Electoral Victory on Local, National, and Transnational Activism by Hmong Americans in Minneapolis-St. Paul." Social Movement Studies 14(2):164-79.

Hellgren, Zenia. 2015. "Immigrant Integration as a Two-Way Process: Translating Theory into Practice.” Working Paper 23. Barcelona: Gritim-Universitat Pompeu Fabra.

Hess, Julia Meredith. 2009. Immigrant Ambassadors: Citizenship and Belonging in the Tibetan Diaspora. Stanford: Stanford University Press.

Hess, Monika and Benedikt Korf. 2014. "Tamil Diaspora and the Political Spaces of Secondgeneration Activism in Switzerland." Global Networks 14(4):419-37.

Huntington, Samuel P. 2004. Who Are We? The Challenges to America's National Identity. New York: Simon \& Schuster.

Jaoul, Nicolas. 2016. "Citizenship in Religious Clothing? Navayana Buddhism and Dalit Emancipation in late 1990s Uttar Pradesh." Focaal 76:46-68.

Jasper, James M., and Jan Willem Duyvendak. 2015. Players and Arenas: The Interactive Dynamics of Protest. Amsterdam: Amsterdam University Press.

Joshi, Barbara. 1986. Untouchable: Voices of the Dalit Liberation Movement. New Delhi: Zed Books. Juergensmeyer, Mark. 1982. Religion as Social Vision: The Movement against Untouchability in $20^{\text {th }}$ Century Punjab. Berkeley: University of California Press.

Juergensmeyer, Mark. 1997. “The ‘Ghadar Syndrome’: Nationalism in an Immigrant Community.” Punjab Journal of Politics (1)1:1-22.

Kauffmann, Thomas. 2015. The Agendas of Tibetan Refugees: Survival Strategies of a Government-InExile in a World of Transnational Organizations. New York and Oxford: Berghahn.

Khan, Zafar. N.d. "Diasporic Communities and Identity Formation: The Post-Colonial Kashmiri Experience in Britain.” Retrieved January 30, 2022 (http://www.rcpbml.org.uk/wdie-07/ DiCoIdFo.htm).

Koopmans, Ruud. 2004. "Migrant Mobilisation and Political Opportunities: Variation among German Cities and a Comparison with the United Kingdom and the Netherlands." Journal of Ethnic and Migration Studies 30(3):449-70. 
Koshy, Susan and Rajagopalan Radhakrishnan, eds. 2008. Transnational South Asians: The Making of a Neo-Diaspora. New Delhi: Oxford University Press.

Kumar, Suneel. 2008. "Linkages between the Ethnic Diaspora and the Sikh Ethno-National Movement in India.” Faultlines 19. Retrived January 30, 2022 (https://www.satp.org/satporgtp/ publication/faultlines/volume19/article4.htm)

Lacroix, Thomas. 2005. "L'Engagement citoyen des Marocains de l'étranger: les migrants et la démocratie dans les pays d'origine." Hommes \& Migrations 1256:89-102.

Levitt, Peggy. 2001. The Transnational Villagers. Berkeley and Los Angeles: University of California Press.

Lyons, Terrence, and Peter Mandaville. 2012. Politics from Afar: Transnational Diasporas and Networks. New York: Columbia University Press.

Massicard, Elise. 2005. L'Autre Turquie. Le Mouvement aléviste et ses territoires. Paris: Presses Universitaires de France.

McAdam, Doug. 1982. Political Process and the Development of Black Insurgency, 1930-1970. Chicago: University of Chicago Press.

McConnell, Fiona. 2016. Rehearsing the State: The Political Practices of the Tibetan Government-in-Exile. Oxford: Wiley-Blackwell.

Mendelsohn, Olivier, and Marika Vicziani. 1998. The Untouchables: Subordination, Poverty and the State in Modern India. Cambridge: Cambridge University Press.

Mohammad-Arif, Aminah. 2014. "Introduction. Imaginations and Constructions of South Asia: An Enchanting Abstraction?” SAMAJ 10. Retrieved January 30, 2022 (https://

journals.openedition.org/samaj/3800)

Mohammad-Arif, Aminah and Christine Moliner. 2007. "Introduction. Migration and Constructions of the Other: Inter-Communal Relationships amongst South Asian Diasporas." SAMAJ 1. Retrieved January 30, 2022 (https://journals.openedition.org/samaj/136)

Morales, Laura, and Marco Giugni. 2011. Social Capital, Political Participation and Migration in Europe: Making Multicultural Democracy Work? London: Palgrave Macmillan.

Morales, Laura, and Miruna Morariu. 2011. “Is 'Home' a Distraction? The Role of Migrants' Transnational Practices in Their Political Integration into Receiving-Country Politics." Pp. 140-71 in Social Capital, Political Participation and Migration in Europe, edited by L. Morales and M. Giugni. United Kingdom: Palgrave Macmillan.

Morawska, Ewa. 2003. "Disciplinary Agendas and Analytic Strategies of Research on Immigrant Transnationalism: Challenges of Interdisciplinary Knowledge." International Migration Review 37(3):611-40.

Nesbitt, Eleanor. 2010. "Religions and Identity: The Valmiki Community in Coventry." Journal of Ethnic and Migration Studies 16(2):261-74.

Nicholls, Walter J. 2013. The DREAMers: How the Undocumented Youth Movement Transformed the Immigrant Rights Debate. Stanford: Stanford University Press.

Nicholls, Walter J. 2019. The Immigrant Rights Movement: The Battle over National Citizenship. Stanford: Stanford University Press.

Olivius, Elisabeth. 2019. “Claiming Rights in Exile: Women's Insurgent Citizenship Practices in the Thai-Myanmar Borderlands.” Citizenship Studies 23(8):761-79. 
Oo, Zaw. 2006. "Exit, Voice, and Loyalty in Burma: The Role of Overseas Burmese in Democratising Their Homeland." Pp. 231-62 in Myanmar's Long Road to National Reconciliation, edited by T. Wilson. Singapore: ISEAS Publications.

Orjuela, Camilla. 2018. "Mobilising Diasporas for Justice: Opportunity Structures and the Presencing of a Violent Past." Journal of Ethnic and Migration Studies 44(8):1357-73.

Orjuela, Camilla. 2020. "Passing on the Torch of Memory: Transitional Justice and the Transfer of Diaspora Identity across Generations." International Journal of Transitional Justice 14(2):360-80.

Østergaard-Nielsen, Eva. 2003. Transnational Politics: The Case of Turks and Kurds in Germany. London: Routledge.

Penninx, Rinus, and Blanca Garcés-Mascareñas. 2016. "The Concept of Integration as an Analytical Tool and as a Policy Concept." Pp. 11-29 in Integration Processes and Policies in Europe: Contexts, Levels and Actors, edited by B. Garcés-Mascareñas and R. Penninx. New-York: Springer International Publishing.

Però, Davide and John Solomos. 2010. "Introduction: Migrant Politics and Mobilization: Exclusion, Engagements, Incorporation.” In Ethnic and Racial Studies 33(1):1-18.

Portes, Alejandro. 1999. "Conclusion: Towards a New World-The Origins and Effects of Transnational Activities." Ethnic and Racial Studies 22(2):463-77.

Portes, Alejandro, Cristina Escobar, and Renelinda Arana. 2008. "Bridging the Gap: Transnational and Ethnic Organizations in the Political Incorporation of Immigrants in the United States." Ethnic and Racial Studies 31(6):1056-90.

Portes, Alejandro, and Rubén G. Rumbaut. 2006. Immigrant America: A Portrait. Berkeley: University of California Press.

Ragazzi, Francesco. 2014. “A Comparative Analysis of Diaspora Policies.” Political Geography 41:7489.

Rao, Anupama. 2009. The Caste Question: Dalits and the Politics of Modern India. Berkeley: University of California Press.

Safran, William. 1999. “Comparing Diasporas: A Review Essay.” Diaspora 8(3):255-91.

Shain, Yoshi. 1999. Marketing the American Creed abroad, Diasporas in the US and their Homelands. Cambridge: Cambridge University Press.

Shani, Giorgio. 2002. "The Territorialization of Identity: Sikh Nationalism in the Diaspora." Studies in Ethnicity and Nationalism 2(1):11-19.

Sheffer, Gabriel. 2003. Diaspora Politics: At Home Abroad. New York: Cambridge University Press. Siméant, Johanna. 1998. La Cause des Sans-Papiers. Paris: Presses de Sciences Po.

Smets, Kevin, Jacinthe Mazzocchetti, Lorraine Gerstmans, and Lien Mostmans. 2019. "Beyond Victimhood: Reflecting on Migrant-Victim Representations with Afghan, Iraqi, and Syrian Asylum Seekers and Refugees in Belgium." Pp. 177-97 in Images of Immigrants and Refugees in Western Europe, edited by L. d'Haenens, W. Joris and F. Heinderyckx. Leuven: Leuven University Press.

Sökefeld, Martin. 2006. "Mobilizing in Transnational Space: A Social Movement Approach to the Formation of Diaspora." Global Networks 6(3):265-84. 
Sökefeld, Martin and Marta Bolognani. 2011. "Kashmiris in Britain: A Political Project or a Social Reality?" Pp. 111-31 in Pakistan and its Diaspora: Multidisciplinary Approaches, edited by M. Bolognani and S. M. Lyon. New York: Palgrave McMillan.

Staton, Jeffrey K., Robert A. Jackson, and Damarys Canache. 2007. "Dual Nationality Among Latinos: What Are the Implications for Political Connectedness?" Journal of Politics 69(2):470-82.

Steinhilper, Elias. 2018. "Mobilizing in Transnational Contentious Spaces: Linking Relations, Emotions and Space in Migrant Activism." Social Movement Studies 17(5):574-91.

Takhar, Opinderjit K. 2017. "British Legislation Against Caste-Based Discrimination and the Demand for the Sunset Clause.” Contemporary South Asia 25(3):301-16.

Tarrow, Sidney G. 1989. Democracy and Disorder: Protest and Politics in Italy, 1965-1975. Oxford: Oxford University Press.

Tatla, Singh. 1999. The Sikh Diaspora: The Search for Statehood. London: UCL Press.

Thobani, Sitara. 2019. "Alt-Right with the Hindu-right: Long-distance Nationalism and the Perfection of Hindutva." Ethnic and Racial Studies 42(5):745-62.

Tilly, Charles. 1978. From Mobilization to Revolution. New York: Random House.

Van der Veer, Peter. 1995. Nation and Migration: The Politics of Space in the South Asian Diaspora. Philadelphia: University of Pennsylvania Press.

Vertovec, Steven. 1997. “Three Meanings of 'Diaspora,' Exemplified among South Asian Religions." Diaspora: A Journal of Transnational Studies 6(3):277-99.

Williams, David C. 2012. "Changing Burma From Without: Political Activism among the Burmese Diaspora.” Indiana Journal of Global Legal Studies 19(1):121-42.

Zederman, Mathilde. 2018. "Trans-State Spaces of Mobilization: Tunisian Activism in France in the Era of Ben Ali (1987-2011)." PhD dissertation, Politics Department, SOAS University of London.

\section{NOTES}

1. We are very grateful to SAMAJ editors Aminah Mohammad-Arif and Pierre-Yves Trouillet for their encouragement and continuous support during the various stages of this Special Issue. We also wish to thank the reviewers for their comments and valuable suggestions on an earlier draft which helped strengthen the argument in many ways.

2. We use "migrants" in this introduction as a generic term referring to all the people who have left the home country and settled in a host country. We use "refugees" only to refer to those migrants who may or may not have refugee status, but who consider, or have considered themselves as refugees-this is the case here for a vast majority of Sri Lankan Tamils, Burmese and Tibetans in Western countries.

3. This wide definition of South Asia, which is sometimes used in South Asian Studies centers, refers to a geographical, cultural or historical, more than to a political South Asia (see Mohammad-Arif 2014 for a discussion of South Asia's fluctuating boundaries). The inclusion of Tibetan and Burmese refugees in this introduction is also based on a strong association with India, which is/was: 1) a refuge for the majority of Tibetans who fled Tibet and a significant number of Burmese (from the Bamar majority and from ethnic minorities such as the Chin), and 2) a headquarter for both governments-in-exile, the National Coalition Government of Burma (NCGUB) (partly) and the Central Tibetan Administration (CTA) (fully). 
4. This estimation is based on the United Nations International Migrant Stock 2019, according to which there were 272 million migrants in the world, including 17.5 million from India, 6.3 million from Pakistan, 7.8 million from Bangladesh, 1.8 million from Sri Lanka, 5.1 million from Afghanistan, 2.3 million from Nepal and 3.7 million from Myanmar (https://www.un.org/en/ development/desa/population/migration/data/estimates2/estimates19.asp).

5. Unless stated otherwise, all references to the Sri Lankan Tamil, Tibetan, Ambedkarite/Dalit and Canadian South Asian cases in this introduction come from these five contributions. Additional references can be found in the contributions themselves.

6. For Betts and Jones (2016), the existence of a diaspora, far from being linear, can move back and forth from periods of seeming death to "diasporic moments," during which the diaspora is reactivated. This idea is further developed by Féron and Lefort (2019) for diasporas forming around a conflict at home.

7. There might not be room for concurrent conceptions, but this does not mean that the dominant view is not contested. Minority segments of the Sikh population, such as the Namdharies, Nirankaries, Radhasoamis or Ravidasis, have been highly critical of the Khalistan movement, which is seen as a way for the Jats, i.e. the most economically advanced caste, to try and dominate the Sikh diaspora (Gayer 2000; Gunawardena 2001; Tatla 1999). Bamar and ethnic Burmese refugees, such as the Chins, the Kachins, the Karens, the Shans and the Rohingyas, are also known to compete against each other for better access to resources and/or attention from international refugee agencies and the political leadership in the countries of residence (Brees 2010; Egreteau 2012:132-34).

8. Demands for recognition can also be addressed to the international community. This happens, for instance, with attempts at becoming a member of the Unrepresented Nations and Peoples Organization (UNPO). While Tibet is still a member today, some of Myanmar's ethnic groups have been members in the past (the Chin, the Karenni, the Mon and the Shan) and other South Asian minority groups, like the Sikhs, have unsuccessfully campaigned to join the organization.

\section{AUTHORS}

\section{ANNE-SOPHIE BENTZ}

Associate Professor in South Asian History, Universite de Paris / CESSMA, Fellow of the Institut Convergences Migrations

\section{LOLA GUYOT}

Sciences Po, Lille; Centre d'études et de recherches administratives politiques et sociales (CERAPS); Institut Convergences Migrations (ICM) 